\title{
Diplostomum and Ornithodiplostomum scardinii (Diplostomidae, Digenea) species from naturally infected birds (Anatinae) in the Czech Republic and in Poland: morphological, morphometric and ecological features
}

\author{
J. SITKO ${ }^{1}$, I. RZĄD ${ }^{2}$ \\ ${ }^{1}$ Comenius Museum, Moravian Ornithological Station, Horní nám. 7, 75002 Přerov, Czech Republic, \\ E-mail: sitko@prerovmuzeum.cz; ${ }^{2}$ Department of Ecology and Environmental Protection, University of Szczecin, \\ 13 Wąska St., 75-415 Szczecin, Poland, E-mail: Izabela.rzad@univ.szczecin.pl
}

\begin{abstract}
Summary
The study aimed to describe morphological and morphometric characteristics of species representing the genera Diplostomum Nordmann, 1832 and Ornithodiplostomum Dubois, 1936, originating from naturally infected birds in the Czech Republic and in Poland, and to compare their species richness and the intensity of infection in their avian hosts. Diplostomum mergi Dubois, 1932, D. parviventosum Dubois, 1932, D. phoxini (Faust, 1918), D. pusillum (Dubois, 1928), and Ornithodiplostomum scardinii (Schulman, 1952) were found in the gossander (Mergus merganser). D. parviventosum was found in the velvet scoter (Melanitta fusca). D. pungitii Shigin, 1965 was found in the tufted duck (Aythya fuligula), common eider (Somateria mollissima), common goldeneye (Bucephala clangula), and in the long-tailed duck (Clangula hyemalis). D. spathaceum (Rudolphi, 1819) was found in the mallard (Anas platyrhynchos). Morphology and morphometry of those Diplostomum species from the Czech Republic and from Poland were not analyzed before. The morphological and morphometric description of the adult form of $O$. scardinii presented in this study has been the first such description of a specimen obtained from a naturally infected bird. The highest intensity of infection was observed in the gossander (D. pusillum and D. mergi). Study results provided new data on the occurrence of the Diplostomum and O. scardinii trematodes in the Czech Republic and in Poland.
\end{abstract}

Keywords: Diplostomidae; mature trematodes; morphology; anseriform birds

\section{Introduction}

The Czech Republic and Poland represent environmental conditions characteristic for Central Europe; diplostomidean trematodes have been recorded in both intermediate hosts and definitive hosts under such conditions. In the
Czech Republic, 8 Diplostomum species and 18 other species from the family Diplostomidae Poirier, 1886 have been recorded in 16 bird species (Sitko et al., 2006). In Poland, only 10 Diplostomum species and 15 other species from the family Diplostomidae have been recorded so far (Pojmańska et al., 2007). The knowledge about the trematodes representing the genera Diplostomum Nordmann, 1832, and Ornithodiplostomum Dubois, 1936 is not complete, since not all of the species have been found on both the intermediary and the definitive hosts in naturally infected birds.

The knowledge about the morphology of the Diplostomidae has mostly been acquired from experimental studies (Dubois, 1970; Schigin, 1993; see Niewiadomska, 2010), and not from naturally infected hosts. Thanks to the study by Niewiadomska (1984), the morphology and morphometry of Diplostomum spathaceum (Rudolphi, 1819) and D. pseudospathaceum Niewiadomska, 1984 are very wellknown, making it possible to distinguish between these two species. The morphology, including the sizes of adult forms of other Diplostomum and Ornithodiplostomum species occurring in the Czech Republic and in Poland have not been described before.

Potential definitive hosts of the trematodes representing the family Diplostomidae are those birds which have fish and amphibians as either a regular or an accidental component of their diet. Such birds include i.a. the gossander (Mergus merganser), smew (Mergus albellus), tufted duck (Aythya fuligula), long-tailed duck (Clangula hyemalis), common goldeneye (Bucephala clangula), velvet scoter (Melanitta fusca), black tern (Chlidonias niger), common tern (Sterna hirundo), red-throated loon (Gavia stellata), common eider (Somateria mollissima) and seagulls (Laridae).

Those birds differ with respect to biology, habitat, diet, and a manner of acquiring food, and fish are a more or less important component of their diets. In the Czech Republic, 
in the gossander, a typical fish-eating species, 4 species of the Diplostomidae have been recorded: Diplostomum mergi Dubois, 1932, D. parviventosum Dubois, 1932, D. pusillum (Dubois, 1928), and Ornithodiplostomum scardinii (Shulman, 1952) (Sitko et al. 2006). While studying the gossander in north-western Poland, Kavetska et al. (2008a) recorded D. mergi, D. parviventosum, D. phoxini (Faust, 1918), D. pusillum, Diplostomum sp. and O. scardinii. Comprehensive parasitological studies of the tufted duck have been conducted in Poland, but in spite of their considerable scope no trematodes representing the Diplostomidae have been found in that host (Sitko et al., 2006; Pojmańska et al., 2007; Rząd et al., 2013). In the Czech Republic, D. pungitii has been found in the long-tailed duck and the common eider (Sitko et al., 2006). In the mallard (Anas platyrhynchos), D. spathaceum (Rudolphi, 1819) has been found in the Czech Republic (Sitko et al., 2006) and T. excavata (Rudolphi, 1803) in Poland (Sulgostowska \& Czaplińska, 1987). In both countries, the Diplostomidae have not been found before in the common goldeneye and the velvet scoter (see Pojmańska et al., 2007; Rząd et al., 2007).

Available data on worldwide occurrence of the respective species of the Diplostomum and Ornithodiplostomum are diversified. In the Czech Republic, Diplostomum mergi, D. parviventosum, D. pungitii Schigin, 1965, D. pusillum and D. phoxini have been found by Sitko (Sitko et al., 2006). Furthermore, D. mergi has been recorded in Switzerland (Dubois, 1970), Germany (Odening, 1978), Poland
(Sulgostowska, 1958; Kavetska et al., 2008b), Ukraine (Smogorzevskaya, 1976), Russia (Schigin, 1993), Far East (Schigin, 1993), Azerbaijan (Vaidova, 1978), Japan (Yamaguti, 1971), and Alaska (Dubois, 1970). D. parviventosum has been found in Switzerland, UK (Dubois, 1970), and Russia (Schigin, 1993). Furthermore, subject literature mentions records from Chlidonias niger and Larus argentatus in the Ukraine (Sergeeva, 1973), and from L. ridibundus in Kyrgyzstan (Tokobaev \& Tschibichenko, 1978). In Poland, the cercariae (Niewiadomska \& Laskowski, 2002) and adult forms (Niewiadomska, 2003) of D. parviventosum have been found. D. pungitii has been described from Lithuania, Latvia, Estonia, Russia (Schigin, 1993), and the Far East (Schigin, 1993). In Poland, metacercariae of D. pungitii have been found in fish (Niewiadomska, 2003; Sulgostowska \& Vojtkova, 2005). D. pusillum has been recorded in Romania, Switzerland (Dubois, 1970), Germany (Odening, 1978), Poland (Sulgostowska \& Czaplińska, 1987; Kavetska et al., 2008b), Ukraine (Smogorzevskaya, 1976), Russia (Schigin, 1993), Alaska (Dubois, 1970), Far East (Schigin, 1993), and Japan (Yamaguti, 1971). There have also been records from Larus argentatus and L. ridibundus in Kyrgyzstan (Tokobaev \& Tschibichenko, 1978). D. phoxini has been found in Alaska, Switzerland, UK (Dubois, 1970), Russia, Ukraine (Schigin, 1993), and Poland (Kavetska, 2008b). O. scardinii has been found in Russia and the Ukraine (Schigin, 1993), and recently also in Poland (Rząd et al., 2007). Furthermore, the following trematodes have been found in avian hosts in the Czech Republic: Diplosto-

Table 1 . The number of bird specimens and locations where they were found

\begin{tabular}{|c|c|c|}
\hline Host species & $\begin{array}{l}\text { Number } \\
\text { of examined } \\
\text { brids }\end{array}$ & Locations where the birds were found \\
\hline Anas platyrhynchos & 497 & $\begin{array}{l}\text { Bartošovice } 49^{\circ} 40^{\prime} \mathrm{N}, 18^{\circ} 03^{\prime} \mathrm{E}, \text { Hodonin } 48^{\circ} 50^{\prime} \mathrm{N}, 17^{\circ} 07^{\prime} \mathrm{E}, \\
\text { Hustopeče nad Bečvou } 49^{\circ} 31^{\prime} \mathrm{N}, 17^{\circ} 52^{\prime} \mathrm{E} \text {, Lomnice nad Lužnicí } 49^{\circ} 05^{\prime} \\
\mathrm{N}, 14^{\circ} 43^{\prime} \mathrm{E} \text {, Napajedla } 49^{\circ} 10^{\prime} \mathrm{N}, 17^{\circ} 30^{\prime} \mathrm{E} \text {, Prerov, Strachotín, Tovačov } \\
49^{\circ} 25^{\prime} \mathrm{N}, 17^{\circ} 17^{\prime} \mathrm{E} \text {, Záhlinice, Brno } 49^{\circ} 11^{\prime} \mathrm{N}, 16^{\circ} 36^{\prime} \mathrm{E}(\mathrm{CR})\end{array}$ \\
\hline Aythya fuligula & 231 & Záhlinice \\
\hline Bucephala clangula & 7 & Záhlinice \\
\hline Clangula hyemalis & 80 & Gdańsk $54^{\circ} 21^{\prime} \mathrm{N}, 18^{\circ} 38^{\prime} \mathrm{E}$ (PL) \\
\hline \multirow[t]{2}{*}{ Melanitta fusca } & 2 & Praha $50^{\circ} 04^{\prime} \mathrm{N}, 14^{\circ} 26^{\prime} \mathrm{E}(\mathrm{CR})$ \\
\hline & 18 & Gdańsk \\
\hline Mergus merganser & 19 & $\begin{array}{l}\text { Záhlinice, Strachotín } 48^{\circ} 54^{\prime} \mathrm{N}, 16^{\circ} 39^{\prime} \mathrm{E} \text {, Veselí nad Moravou } 48^{\circ} 57^{\prime} \mathrm{N} \text {, } \\
17^{\circ} 22^{\prime} \mathrm{E}, \text { Měŕín } 49^{\circ} 23^{\prime} \mathrm{N}, 15^{\circ} 53^{\prime} \mathrm{E} \text {, Olomouc } 49^{\circ} 35^{\prime} \mathrm{N}, 17^{\circ} 15^{\prime} \mathrm{E} \text { (CR) }\end{array}$ \\
\hline \multirow[t]{2}{*}{ Somateria mollissima } & 6 & $\begin{array}{l}\text { Kojetín, } 49^{\circ} 21^{\prime} \mathrm{N}, 17^{\circ} 18^{\prime} \mathrm{E} \text {, Přerov } 49^{\circ} 27^{\prime} \mathrm{N}, 17^{\circ} 27^{\prime} \mathrm{E} \text {, Záhlinice } 49^{\circ} \\
17^{\prime} \mathrm{N}, 17^{\circ} 29^{\prime} \mathrm{E}(\mathrm{CR})\end{array}$ \\
\hline & 10 & Gdańsk \\
\hline
\end{tabular}

CR - Czech Republic; PL - Poland 
mum commutatum (Diesing, 1850), D. gavium (Guberlet, 1922), D. pseudospathaceum (Niewiadomska, 1984), D. spathaceum (Rudolphi, 1819) and D. volvens Nordmann, 1832 (Sitko et al., 2006). Adult forms of Diplostomum spathaceum, D. volvens (synonym D. baeri Dubois, 1937), D. commutatum and D. gavium have been recorded in Poland (Sulgostowska, 2007).

The present study aimed to provide the morphological and morphometric characteristics of the trematodes Diplostomum and Ornithodiplostomum scardinii from naturally infected birds in the Czech Republic and in Poland, and to compare their species richness as well as the intensity of infection in the avian hosts of those trematodes: the tufted duck, common eider, common goldeneye, mallard, longtailed duck, gossander and the velvet scoter.

\section{Material and methods}

Collection and examination of birds and digeneans During the period of accessioning parasitic helminths for the museum collection of the Moravian Ornithological Station, Komenský Museum in Přerov, Czech Republic (years 1962-2013), 762 duck specimens from freshwater reservoirs in the Czech Republic and 108 duck specimens from the Baltic Sea in Poland were examined (see Table 1). Helminthological necropsies were conducted. Trematodes were fixed in $70 \%$ alcohol, stained with borax-carmine, dehydrated in the alcohol series, rinsed in xylene and mounted in Canada balsam.

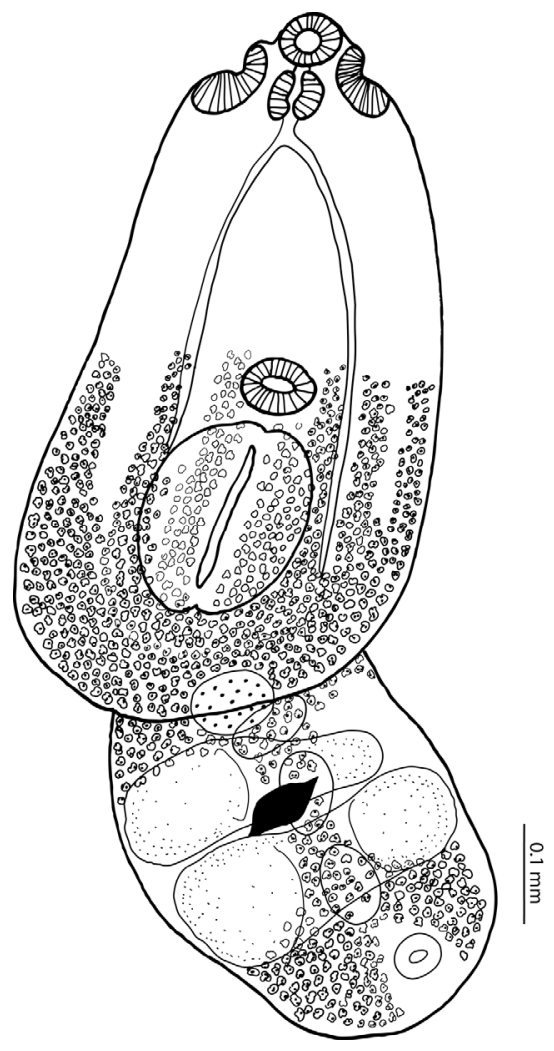

Fig. 1. Diplostomum mergi Dubois, 1932
Data analysis

Systematic classification and nomenclature of the trematodes were based on morphological descriptions and morphometric data found in the works by Dubois (1970), Schigin (1993) and Niewiadomska (2010). Morphological descriptions and biometric measurements of adult trematode individuals, based on the authors' own materials, were completed for 9-30 specimens of the respective trematode species, taking into account: body size, including the forebody and the hindbody; segment length ratio, size of the oral sucker, praepharynx, pharynx, oesophagus, pseudosuckers, acetabulum, ovary, and testes, as well as the number and size of eggs. Length and width ranges (minmax) of the body and internal organs of the trematodes are given in millimeters $(\mathrm{mm})$ or micrometers $(\mu \mathrm{m})$, in parentheses, beside the ranges; mean values and standard deviation $(\bar{\chi} \pm S D)$ are given. Descriptions refer to mature trematode specimens with developed eggs in the uterus. Species richness was expressed by the number of trematodes in the respective host species. Mean intensity of infection and intensity range were determined (Bush et al., 1997). Documentary material is stored in the collection of Moravian Ornithological Station, Komenský Museum in Přerov, Czech Republic.

\section{Results}

\section{Morphometrics and specimen description}

The following species were recorded: Diplostomum mergi, D. parviventosum, D. phoxini, D. pungitii, D. pusillum, D. spathaceum and Ornithodiplostomum scardinii. The trematodes, with the exception of $D$. phoxini, were well-developed, with developed eggs in the uterus. The population of $D$. phoxini comprised juvenile specimens. The specimen of $D$. spathaceum from the mallard was poorly developed, immature, with no eggs in the uterus, and for those reasons no measurements were conducted. The morphology of $D$. spathaceum was in accordance with the description given by Niewiadomska (1984).

Diplostomum mergi Dubois, 1932

The body: $0.805-1.386(1.104 \pm 0.200) \mathrm{mm}$ long, with a characteristic, distinctive division into segments (Fig. 1). The forebody oval and longer than the hindbody: $477-$ $894(694 \pm 127) \times 298-484(323 \pm 730) \mu \mathrm{m}$. The hindbody also oval, narrower than the forebody: $358-700$ $(452 \pm 101) \times 238-452(287 \pm 640) \mu \mathrm{m}$. Segment length ratio: $50-97(75 \pm 12)$. The oral sucker subterminal: $48-$ $72(54 \pm 9) \times 48-77(54 \pm 10) \mu \mathrm{m}$. The praepharynx visible only in a small number of specimens, 7-18 $(12 \pm 2) \mu \mathrm{m}$ long. The pharynx oblong, oval: $50-72$ $(57 \pm 11) \times 30-67(40 \pm 8) \mu \mathrm{m}$; it is usually placed directly behind the oral sucker. The oesophagus short: $24-$ $72(42 \pm 15) \mu \mathrm{m}$. The intestine bifurcates far from the acetabulum; intestinal branches long, reaching to the rear end of the body. Capsule-forming pseudosuckers: $43-120$ $(72 \pm 17) \times 36-96(39 \pm 12) \mu \mathrm{m}$; they end beyond the 
posterior edge of the pharynx. The acetabulum wide and oval, larger than the oral sucker, located slightly towards the front of the middle part of the forebody, in front of the Brandes' organ and a little distance away from it: $48-77$ $(66 \pm 11) \times 55-101(74 \pm 16) \mu \mathrm{m}$. Sucker length ratio: $0.80-1.44(1.01 \pm 0.16)$; sucker width ratio: $0.78-1.85$ $(1.27 \pm 0.24)$. Brandes' organ oblong, oval: $116-261$ $(183 \pm 32) \times 128-232(165 \pm 30) \mu \mathrm{m}$. The ovary wide, oval: $58-116(69 \pm 13) \times 58-116(77 \pm 11) \mu \mathrm{m}$; situated near the border between segments. Vitellaria welldeveloped in both parts of the body. Three small distinctive projections of small follicles situated regularly in front of the Brandes' organ. The vitellarium in the forebody reaches beyond the acetabulum. In the hindbody, in the region of the dorsal side of the posterior testis, the vitellaria become narrower, split behind it and reach up to the end of the body. The anterior testis asymmetrical, from above: $116-174(125 \pm 19) \times 174-348(253 \pm 47) \mu \mathrm{m}$. The posterior testis symmetrical, long and oval: $104-174$ $(132 \pm 22) \times 174-348(254 \pm 47) \mu \mathrm{m}$. The uterus contains a small number $(2-10)$ of eggs: $96-122(120 \pm 6) \times 53-$ $84(63 \pm 9) \mu \mathrm{m}$.

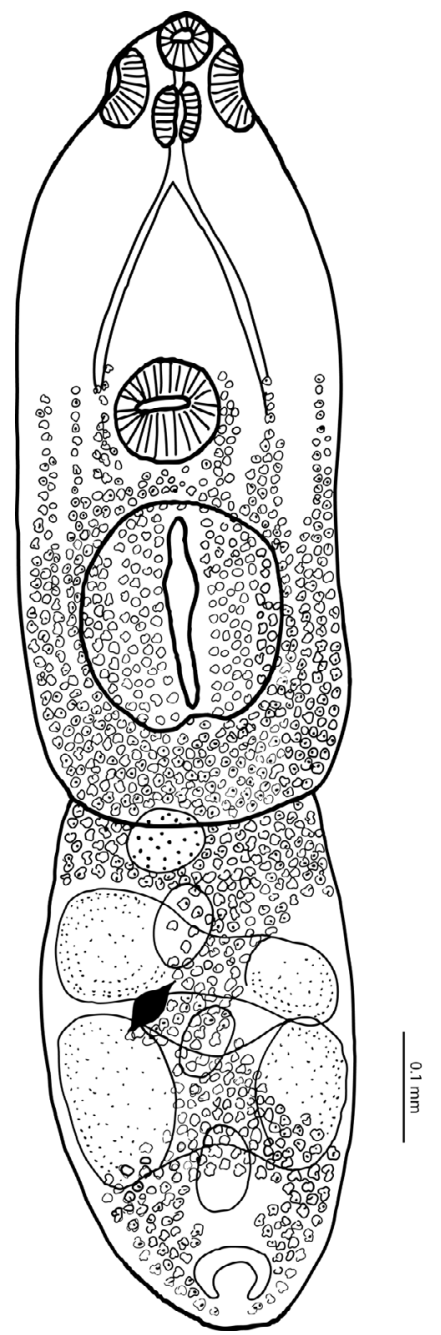

Fig. 2. Diplostomum parviventosum Dubois, 1932
Diplostomum parviventosum Dubois, 1932

The body: $0.936-1.543(1.158 \pm 0.124) \mathrm{mm}$ long, with an indistinct division into segments (Fig. 2). The forebody elongated, oval: $536-864(732 \pm 94) \times 238-328$ $(282 \pm 21) \mu \mathrm{m}$; longer than the hindbody. The hindbody oval: $298-514(429 \pm 94) \times 194-298(246 \pm 22) \mu \mathrm{m}$. Segment length ratio: $0.38-0.83(0.57 \pm 0.11)$. The oral sucker subterminal: $43-60(52 \pm 4) \times 38-60(50 \pm 5)$ $\mu \mathrm{m}$. The praepharynx developed in a small number of specimens only; $7-18(12 \pm 2) \mu \mathrm{m}$ long. The pharynx oblong and oval: $48-62(53 \pm 5) \times 29-43(39 \pm 4) \mu \mathrm{m}$. The oesophagus: $24-72(42 \pm 15) \mu \mathrm{m}$. Behind it, the intestine bifurcates. Capsule-forming pseudosuckers: $48-$ $96(70 \pm 9) \times 24-53(34 \pm 5) \mu \mathrm{m}$; they end at the level of the rear end of the pharynx. The acetabulum situated in front of the Brandes' organ, distinctly larger than the oral sucker: $53-84(72 \pm 8) \times 60-96(80 \pm 8) \mu \mathrm{m}$. Sucker length ratio: $1.06-1.75(1.40 \pm 0.18)$; sucker width ratio: $1.30-2.0(1.62 \pm 0.22)$. The Brandes' organ oblong and oval: $144-261(189 \pm 31) \times 108-203(150 \pm 23) \mu \mathrm{m}$. The ovary wide and oval: $48-87(61 \pm 8) \times 58-99$ (72 \pm 11$) \mu \mathrm{m}$; situated near the border between segments, at the front edge of the hindbody. Vitellaria well-developed in both parts of the body. In the forebody, the vitellaria surround the Brandes' organ and reach forward beyond the acetabulum. In the hindbody, behind the posterior testis they form two laterally situated clusters and reach up to the end of the body. The anterior testis asymmetrical; from above: $87-128(101 \pm 18) \times 162-261(211 \pm 27) \mu \mathrm{m}$. The posterior testis symmetrical: $70-128(109 \pm 16) \times$ $157-261(212 \pm 28) \mu \mathrm{m}$. The uterus contains a small number $(2-8)$ of eggs, $101-127(115 \pm 6) \times 60-84$ $(72 \pm 6) \mu \mathrm{m}$.

\section{Diplostomum pungitii Shigin, 1965}

The body $1.147-1.600(1.317) \mathrm{mm}$ long, with an indistinct division into segments (Fig. 3). The forebody oval: $641-864(741) \times 402-596(458) \mu \mathrm{m}$; larger than the hindbody. The hindbody oval: $492-826(655) \times 328-$ 417 (389) $\mu \mathrm{m}$. Segment length ratio: $0.72-1.06(0.88)$. The oral sucker subterminal, oval: $60-96(73) \times 70-96$ (78) $\mu \mathrm{m}$. The praepharynx developed in a small number of specimens only, $7-14$ (10) $\mu \mathrm{m}$ long. The pharynx oblong and oval: $72-96(81) \times 36-64(53) \mu \mathrm{m}$. The oesophagus: $24-60(40) \mu \mathrm{m}$. Characteristic, very large pseudosuckers: $96-232(185) \times 70-133(98) \mu \mathrm{m}$; they reach beyond the bifurcation of the intestine. The acetabulum wide, oval, in front of the Brandes' organ, slightly larger than the oral sucker: $67-87(79) \times 77-104(90) \mu \mathrm{m}$. Sucker length ratio: $0.75-1.33$ (1.11); sucker width ratio: $1.00-1.49$ (1.16). The Brandes' organ oval: $232-290(259) \times 186-$ $290(245) \mu \mathrm{m}$. The ovary wide, oval: $58-116(77) \times 87-$ 145 (100) $\mu \mathrm{m}$; situated near the border between segments. Vitellaria well-developed in both parts of the body. In the forebody, the vitellarium reaches up to the anterior edge of the acetabulum. In the hindbody they form two laterally situated clusters and reach up to the end of the body. The 


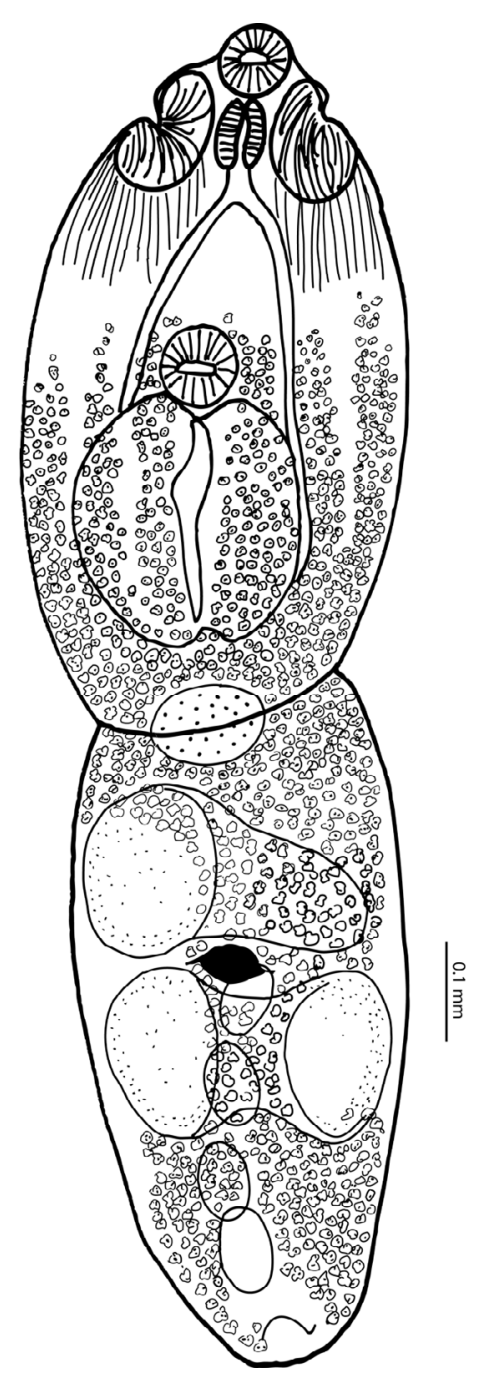

Fig. 3. Diplostomum pungitii Shigin, 1965

anterior testis asymmetrical; from above: $145-203$ (168) $\times 232-377(335) \mu \mathrm{m}$. The posterior testis symmetrical, long, and oval: $145-273(208) \times 261-348(316) \mu \mathrm{m}$. The uterus contains a small number $(2-4)$ of eggs: $93-130$ (119) $\times 65-72(70) \mu \mathrm{m}$.

Diplostomum pusillum (Dubois, 1928)

The body $0.754-1.003(0.861 \pm 0.085) \mathrm{mm}$ long (Fig. 4), with a distinct division into segments. The forebody oval, almost round: $460-662(529 \pm 72) \times 255-414(328 \pm 55)$ $\mu \mathrm{m}$. The hindbody oval: $366-460(399 \pm 32) \times 230-368$ $(332 \pm 43) \mu \mathrm{m}$. Segment length ratio: $1.00-1.99$ $(1.41 \pm 0.28)$. The oral sucker subterminal, oval: $36-62$ $(51 \pm 8) \times 48-72(53 \pm 7) \mu \mathrm{m}$. The praepharynx developed in a small number of specimens only, $7-18(12 \pm 2)$ $\mu \mathrm{m}$ long. The pharynx spherical: $53-72(62 \pm 6) \times 36-$ $53(40 \pm 6) \mu \mathrm{m}$. The oesophagus: $24-72(42 \pm 15) \mu \mathrm{m}$. Behind it, the intestine bifurcates. Capsule-forming pseudosuckers: $43-96(64 \pm 16) \times 24-53(40 \pm 7) \mu \mathrm{m}$. The acetabulum wide, oval, situated near the intestinal bifurcation: $48-70(53 \pm 8) \times 48-77(62 \pm 9) \mu \mathrm{m}$. Sucker length ratio: $0.61-1.60(1.08 \pm 0.26)$; sucker width ratio: $0.68-$ $1.2(1.19 \pm 0.25)$. The Brandes' organ oblong, oval: $145-$ $322(189 \pm 48) \times 96-276(151 \pm 45) \mu \mathrm{m}$. The ovary wide, oval: $36-116(57 \pm 21) \times 48-116(80 \pm 20) \mu \mathrm{m}$, situated at the front edge of the hindbody, adjoins the anterior testis. Vitellaria well-developed in both parts of the body. In the forebody, the vitellaria reach up to the level of the intestinal bifurcation. The anterior testis asymmetrical; from above: $65-116(91 \pm 17) \times 157-290(219 \pm 35)$ $\mu \mathrm{m}$. The posterior testis symmetrical, long, oval: $58-116$ $(98 \pm 24) \times 145-262(210 \pm 35) \mu \mathrm{m}$. The uterus contains a small number $(2-10)$ of eggs: $101-122(113 \pm 55) \times$ $70-84(74 \pm 5) \mu \mathrm{m}$.

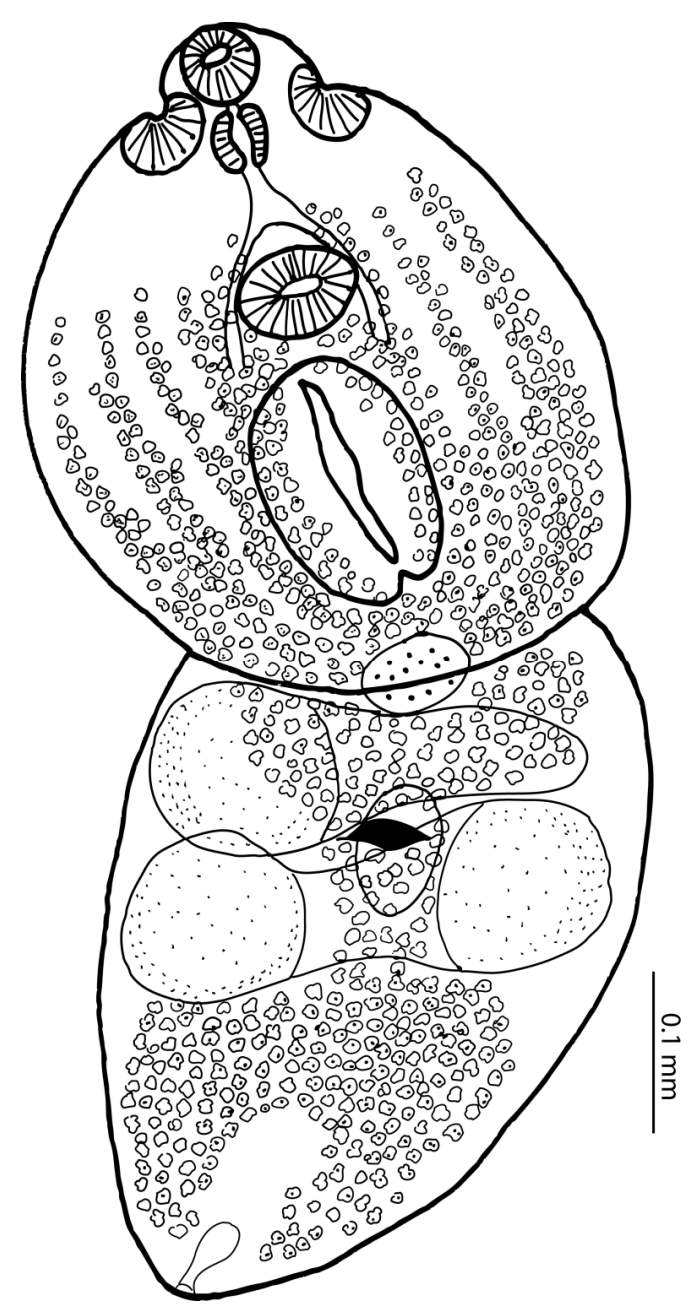

Fig. 4. Diplostomum pusillum (Dubois, 1928)

\section{Diplostomum phoxini (Faust, 1918)}

The body $0.672-1.49(1.036 \pm 0.193) \mathrm{mm}$ long, with a characteristic, distinctive division into segments (Fig. 5). The forebody oval: $524-1088(668 \pm 118) \times 276-447$ $(346 \pm 42) \mu \mathrm{m}$. The hindbody oval: $294-671(360 \pm 91) \times$ $268-0.373(313 \pm 26) \mu \mathrm{m}$, considerably smaller, i.e. shorter and narrower than the forebody. Segment length ratio: $0.95-2.43(1.80 \pm 0.35)$. The oral sucker subtermi- 
nal, round: $41-75(59 \pm 10) \times 41-75(59 \pm 9) \mu \mathrm{m}$. The pharynx: $46-75(63 \pm 7) \times 24-48(35 \pm 7) \mu \mathrm{m}$; it adjoins the oral sucker directly. The oesophagus: 24-72 $(42 \pm 15) \mu \mathrm{m}$. Behind it, the intestine bifurcates. Capsuleforming pseudosuckers: $70-190(97 \pm 29) \times 29-70$ (43 \pm 14$) \mu \mathrm{m}$; they restrict the oral sucker from both sides, beginning at the level of the posterior end of the oral sucker and ending at the level of the rear end of the pharynx. The acetabulum situated almost in the middle of the anterior segment: $46-75(63 \pm 8) \times 58-96(70 \pm 11)$ $\mu \mathrm{m}$; slightly in front of the Brandes' organ. Sucker length ratio: $0.79-1.60(1.08 \pm 0.21)$; sucker width ratio: $0.85-$ $1.92(1.19 \pm 0.24)$. The Brandes' organ oval: $87-290$ $(174 \pm 53) \times 87-203(135 \pm 35) \mu \mathrm{m}$; it adjoins the acetabulum. The ovary situated centrally in front of the testes, at the front edge of the hindbody: 58-145 $(68 \pm 20) \times 58-145(82 \pm 24) \mu \mathrm{m}$. Vitellaria welldeveloped in both parts of the body. In the forebody, they

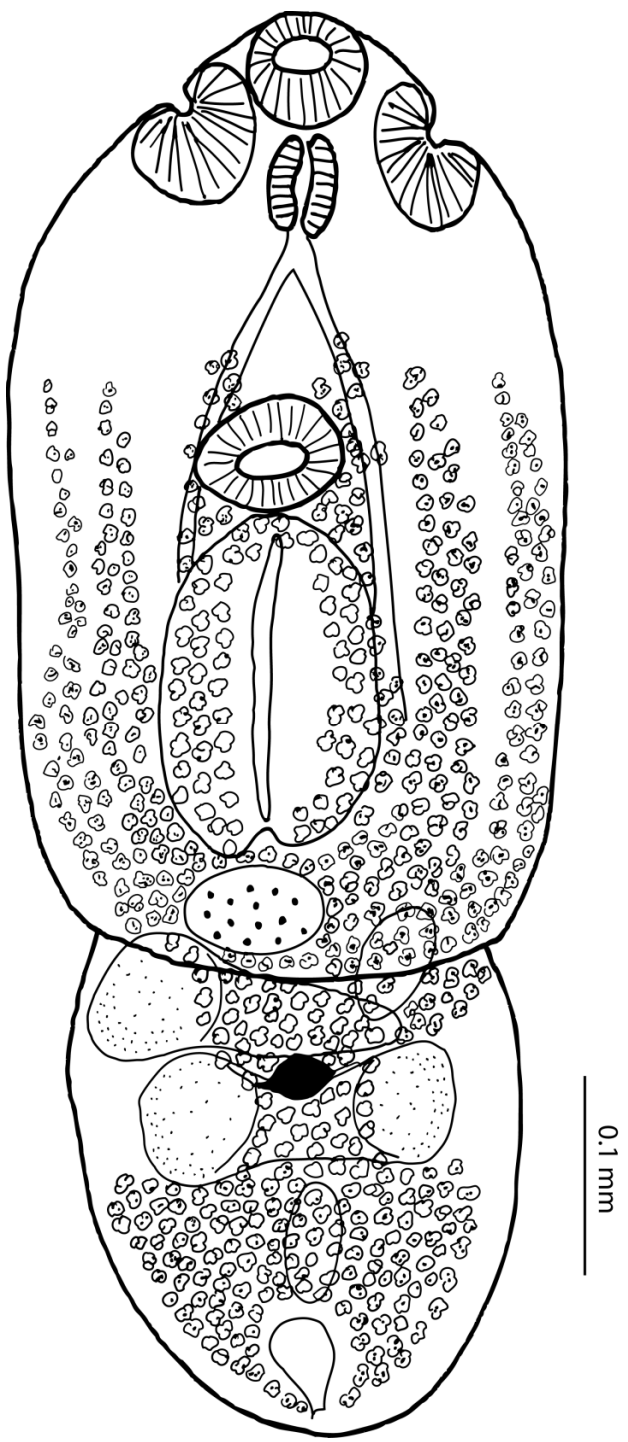

Fig. 5. Diplostomum phoxini (Faust, 1918) form the largest cluster in the region of the Brandes' organ. In the front part of the segment, on each side the vitelline, follicles form 3 forward-oriented strands reaching beyond the edge of the acetabulum. In the hindbody, vitellaria form a cluster of vitelline follicles in the central part of the hindbody and two large clusters of vitelline follicles in the posterior part of the segment. The anterior testis asymmetrical, covered by the forebody, from above: $58-$ $170(100 \pm 26) \times 186-290(237 \pm 29) \mu \mathrm{m}$. The posterior testis symmetrical, long, oval: $70-220(108 \pm 36) \times 186-$ $319(229 \pm 33) \mu \mathrm{m}$. The uterus contains a small number $(2-8)$ of eggs: $106-128(119 \pm 5) \times 70-87(83 \pm 5) \mu \mathrm{m}$.

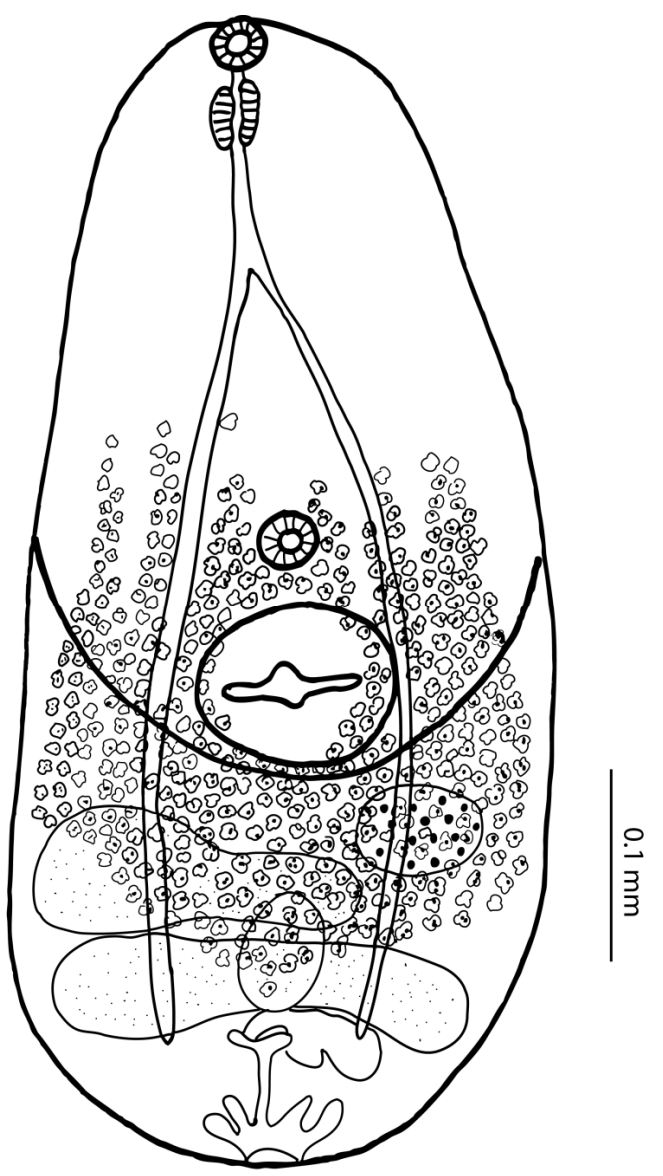

Fig. 6. Ornithodiplostomum scardinii (Schulman, 1952)

Ornithodiplostomum scardinii (Schulman, 1952)

The body oval, $0.476-0.828(0.704 \pm 0.091) \mathrm{mm}$ long, $0.186-0.331(0.284 \pm 0.041) \mathrm{mm}$ wide, with no distinct division into segments (Fig. 6). Length and width ratios: $2.20-3.40(2.52 \pm 0.37)$. The oral sucker subterminal: $24-43(33 \pm 6) \times 29-38(32 \pm 3) \mu \mathrm{m}$. The praepharynx practically absent or very short, developed in a small number of specimens only, $7-12(10 \pm 2) \mu \mathrm{m}$ long. The pharynx oblong and oval: $34-48(42 \pm 5) \times 22-48(27 \pm 4)$ $\mu \mathrm{m}$. The oesophagus short: $24-72(42 \pm 15) \mu \mathrm{m}$. Behind it, the intestine bifurcates at the point situated slightly further than half of the distance between the pharynx and the acetabulum. The acetabulum slightly smaller than the 
oral sucker: $24-38(30 \pm 4) \times 24-36(31 \pm 4) \mu \mathrm{m}$. Sucker length ratio: $0.67-1.32(0.89 \pm 0.20)$; sucker width ratio: $0.81-1.24(0.92 \pm 0.24)$. The Brandes' organ oval: $84-145(112 \pm 16) \times 96-183(120 \pm 21) \mu \mathrm{m}$. The ovary spherical, situated beside the anterior testis: $24-58$ $(40 \pm 10) \times 36-81(54 \pm 12)$. Vitellaria well-developed in both parts of the body. In the forebody, the vitellaria reach slightly beyond the front edge of the acetabulum. In the hindbody, they reach almost up to the rear edge of the posterior testis. The anterior testis asymmetrical: $48-122$ $(80 \pm 19) \times 168-290(229 \pm 29) \mu \mathrm{m}$. The posterior testis symmetrical, long and oval: $48-99(72 \pm 13) \times 120-249$ $(200 \pm 30) \mu \mathrm{m}$. A large seminal vesicle beyond the posterior testis, poorly visible in the examined trematode specimens. The uterus contains a small number $(2-8)$ of eggs: $84-106(98 \pm 7) \times 60-79(70 \pm 6) \mu \mathrm{m}$.

\section{Species richness and intensity of infection}

The gossander turned out to be the host in which the Diplostomidae fauna was the richest with respect to the number of species and the intensity of infection (Table 2). Five species: Diplostomum pusillum, D. phoxini, D. parviventosum, D. mergi, and O. scardinii were found in the gossander. Only one species was found in each of the remaining hosts: D. pungitii in the tufted duck, common eider, common goldeneye and the long-tailed duck, D. parviventosum Dubois, 1932 in the velvet scoter, and D. spathaceum in the mallard. The highest number of gossander individuals were infected with $D$. mergi and $O$. scardinii, (7 and 6 respectively out of the 19 examined hosts). The highest intensity of infection was observed in the gossander $(D$. pusillum and D. mergi). D. parviventosum occurred with a higher intensity in the gossander than in the velvet scoter.

\section{Discussion}

The morphological descriptions of Diplostomum mergi and D. parviventosum correspond to those given by Dubois (1970; see also Yamaguti, 1975). The morphology of $D$. phoxini, D. pungitii and D. pusillum corresponds to descriptions given by Schigin (1993). The descriptions of $D$. mergi, D. parviventosum D. pungitii and D. pusillum also correspond with descriptions of characters relevant to species identification featured in the identification key (Niewiadomska, 2010). The morphology and morphometry of adult trematode individuals of the species Diplostomum found during the present study had not been described on the basis of specimens from Poland and the Czech Republic before. Most data on morphology and morphometry of trematodes (metacercariae and adult forms) had been obtained from experimental studies and not from natural infections (Schigin, 1993). Morphological differences among various species of the Diplostomum are the strongest at the cercarial stage, less strong at the maturity stage, and the weakest at the metacercarial stage (see Niewiadomska, 2010). Schigin (1993) obtained most adult forms of various species on the basis of the full developmental cycle or raised the adult forms from metacercariae, and therefore was able to clearly specify their species distinctness. Species distinctness of the Diplostomum has also been studied by molecular methods (Niewiadomska \& Laskowski, 2002).

The morphological and morphometric description of the specimens of Ornithodiplostomum scardinii given in the present study has been the first such description from naturally infected birds. Previously, in world literature that trematode was known only from specimens obtained on the basis of experimental studies from one grey heron (Ardea cinerea) individual and from young domestic pigeons (Columba livia f. domestica) (Sudarikov \& Kurochkin, 1968). The morphological description of $O$. scardinii corresponds to that given by Sudarikov \& Kurochkin (1968). The morphometric data obtained presently slightly differ from those obtained by the above authors. In the case of the presently examined specimens of $O$. scardinii, maximum measured dimensions are larger than those obtained experimentally by Sudarikov \& Kurochkin (1968), including: body size $(672-762 \times 182-250 \mu \mathrm{m})$, pharynx $(34-39 \times 28 \mu \mathrm{m})$ and eggs $(89-90 \times 61-62$ $\mu \mathrm{m})$, whereas the dimensions of the anterior testis $(56 \mathrm{x}$ $123 \mu \mathrm{m})$ and posterior testis $(84-180 \times 185 \mu \mathrm{m})$ are smaller (Sudarikov \& Kurochkin, 1968).

\section{Species richness and intensity of infection}

The highest species richness and intensity of infection of the trematodes in the gossander in comparison to the remaining examined birds was an expected study result, because it reflected the fish diet of that bird species. The gossander lives on fish-holding waters. Additionally, communal fishing on favourite lakes in late autumn can be conducive to infection (Cramp \& Simmons, 1978). The bird's diet is supplemented by small amounts of small animals: molluscs, crustaceans, and insects. The tufted duck, common eider, common goldeneye, long-tailed duck and the velvet scoter are not typically piscivorous ducks, but fish acquired together with molluscs and other animal food may sporadically appear in their diets (Cramp \& Simmons, 1978). A majority of gossander hosts are infected with Diplostomum mergi and Ornithodiplostomum scardinii. The latter is a Palearctic species and a characteristic digenean of the Mergus albellus. It has been found in Russia and the Ukraine (Schigin, 1993). Its life cycle with the common bladder snail Physa fontinalis (first intermediate host) and cyprinid fishes (second intermediate hosts) has been described by Sudarikov \& Kurochkin (1968). Its metacercariae, found mainly in the common rudd (Scardinius erythropthalmus), and less frequently also in the white bream (Blicca bjoerkna), common roach ( $R u$ tilus rutilus) and the ruffe (Gymnocephalus cernua), are common in Europe and the European part of Russia (Niewiadomska, 2003). In Poland, it is a frequently encountered parasite of fish, which has been recorded mainly in the common rudd, common roach, silver bream and the common bream (Abramis brama) (Niewiadomska, 2003), 


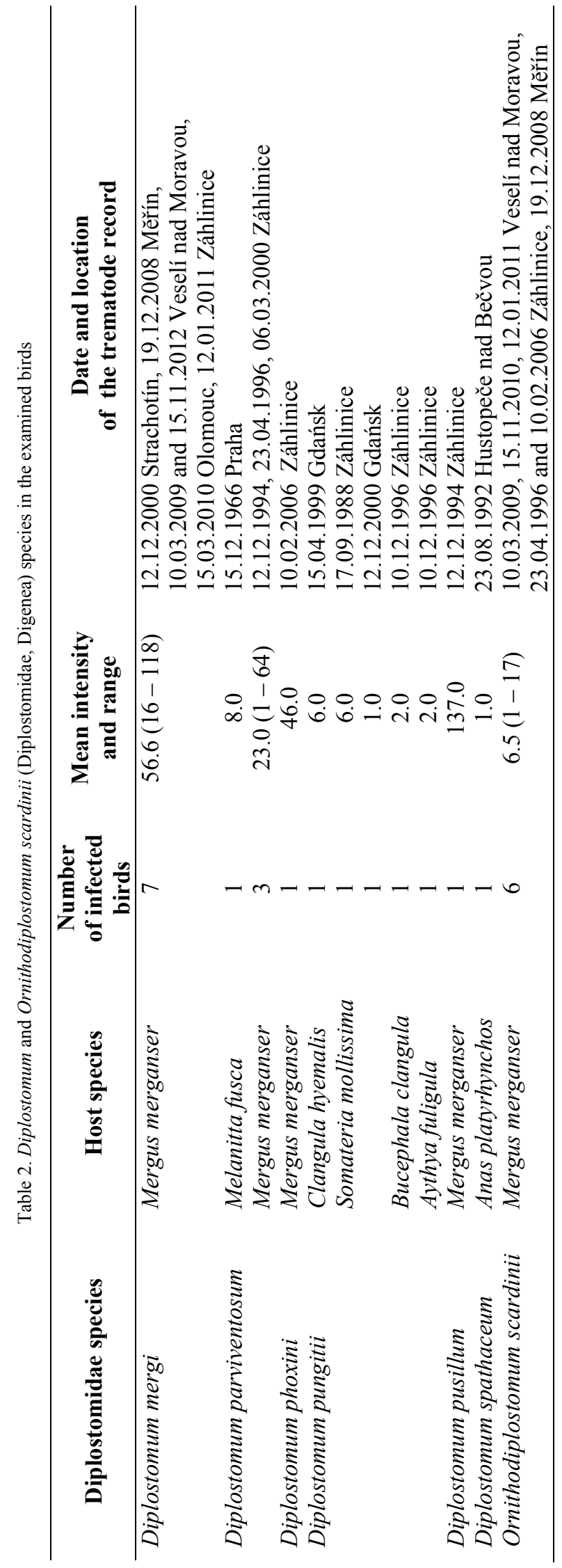


known under the name Neascus scardinii (Schulman) Kozicka, 1958, and usually dwelling in the brain. D. mergi, similarly to $D$. pusillum is a characteristic digenean of fisheating ducks also found in the smew, gossander, and the red-breasted merganser (Mergus serrator), an exceptionally common eider species in the Holarctic. Metacercariae of D. mergi occur in the Cyprinidae and the Percidae (Niewiadomska, 2010). Metacercariae of D. pusillum occur in the stone loach (Barbatula barbatula) (Niewiadomska, 2010). D. parviventosum is a Palaearctic species and a characteristic digenean of the smew. Its metacercariae occur in the peled (Coregonus peled), common roach, sunbleak (Leucaspius delineatus), common rudd, gudgeon (Gobio gobio), white bream, common bream, common carp (Cyprinus carpio) and the perch (Perca fluviatilis) (Niewiadomska, 2003, 2010). D. pungiti is a Palaearctic species and a characteristic digenean of fish-eating ducks, found in the smew and the gossander. Its metacercariae occur in the Ukrainian stickleback (Pungitius platygaster), three-spined stickleback (Gasterosteus aculeatus) and the perch (Niewiadomska, 2010).

In the 1920s, Ruszkowski (1925) described the occurrence of the trematode Hemistomum excavatum (Rud.) in Mergus merganser, but included neither drawings nor biometric data in his study. Newer studies (Niewiadomska, 1963; Grabda-Kazubska, 1972) showed that the species was a synonym to Tylodelphys excavata (Rudolphi, 1803). Dubois (1970) placed Hemistomum excavatum among synonyms of the species Diplostomum (Diplostomum) mergi mergi Dubois, 1932. Intensity of infection in Ruszkowski's studies (1925) equaled 100 individuals per one host, either without eggs or with a small amount of eggs. From the ecological viewpoint it must be taken into consideration that the developmental cycle and specific character of the trematode $T$. excavata exclude the gossander from the range of its hosts. Studies on that trematode species have revealed that its second intermediate hosts are tadpoles and adult amphibians (Niewiadomska, 1963; GrabdaKazubska, 1972). The gossander is a typically piscivorous species. It obtains food diving to the depth of $3 \mathrm{~m}$ (usually) or even $30 \mathrm{~m}$ (occasionally) (Cramp \& Simmons, 1978). These facts indicate that Ruszkowski's (1925) identification of the trematode species in question must have been erroneous. The developmental cycle of $T$. excavata does not allow this trematode to occur with such a high intensity of infection in a non-specific host such as the gossander. $T$. excavata is a typical species for the stork. In the Czech Republic it has been recorded in Ciconia ciconia and $C$. nigra as a dominant species (J. Sitko unpublished). Hosts of that trematode include also the grey heron, western marsh harrier (Circus aeruginosus) and the common buzzard (Buteo buteo) (Pojmańska, 2007). In the Czech Republic it has been recorded from the grey heron, common buzzard (as many as 208 individuals were found in one case), and the tawny owl (Strix aluco) (J. Sitko unpublished). In Poland, 10 individuals of T. excavata have been found in one mallard individual (Bezubik 1956).
Sulgostowska \& Czaplińska (1987) stressed the fact that the mallard might be an accidental host. It was implied by the location of T. excavata individuals in the bird's rectum, which was an untypical location for this trematode. Sulgostowska (2007), informing about the occurrence of $T$. excavata (Rudolphi, 1803) Szidat, 1935 in the stork (Ciconia ciconia) and the marsh harrier from Masurian Lakes in Poland pointed to the fact that that trematode was more characteristic for the stork than for the western marsh harrier (Sulgostowska, 2007). In light of the currently available knowledge about T. excavata, Ruszkowski's (1925) identification seems doubtful. However, since this author's finding took place in the 1920s, an erroneous identification is understandable.

The studies have provided new data on the morphometry and occurrence of the trematodes Diplostomum and Ornithodiplostomum in free-living birds in the Czech Republic and Poland and entirely new scientific data on O. scardinii.

\section{Acknowledgements}

The authors would like to thank Professor Katarzyna Niewiadomska for proofreading the manuscript.

\section{References}

BEZUBIK, B. (1956): [The helminth fauna of wild ducks (subfam. Anatinae)]. Acta Parasitol., 4(10): 407 - 505 (In Polish)

Bush, A. O., Lafferty, K. D., Lotz, J. M., Shostak, A. W. (1997): Parasitology meets ecology on its own terms: Margolis et al. revisited. J. Parasitol., 83(4): 575-583, DOI: $10.2307 / 3284227$

CRAMP, S., Simmons, K. (Eds). (1978): Handbook of the birds of Europe, the Middle East and North Africa: The birds of the Western Palearctic: ostrich to ducks, Vol. 1., Oxford, Oxford University Press

Dubois, G. (1970): Synopsis des Strigeidae et des Diplostomatidae (Trematoda). Mémoires de la Sociéte Neuchâteloise des Sciences Naturelles 10, pp. 259 - 727

GRABDA-KAZUBSKA, B. (1972): [Catalogue of parasitic fauna of Poland, Part III. Parasiti amphibiorum et reptilium], PWN, Warszawa, 111 pp. (In Polish)

KAVETSKA K. M., KRÓlACZYK K., KAlisińsKA E., KORNYUSHIN V. V., KOROL E. N. (2008a): Helminthfauna of the goosander Mergus merganser L., 1758 from the north-western Poland. Wiad. Parazytol., 54(4): 325 - 330 (In Polish)

KAVETSKA, K. M., RZĄD, I., SitKo, J. (2008b): Taxonomic structure of Digenea in wild ducks (Anatidae) from West Pomerania. Wiad. Parazytol., 54(2): 131 - 136

NiEWIADOMSKA, K. (1963): Further studies on the biology and taxonomy of trematodes of the genus Tylodelphys Diesing, 1850 (Diplostomatidae). Acta Parasitol., 11(20): $283-306$

NiEWIAdOMSKA, K. (1984): Present status of Diplostomum spathaceum (Rudolphi, 1819) and differentiation of Diplo- 
stomum pseudospathaceum nom. nov. (Trematoda, Diplostomatidae). Syst. Parasitol., 6(2): 81-86. DOI: 10.1007/BF02185515

NiEWIAdOMSKA, K. (2003): [Parasites of fish in Poland (identification keys). Flukes-Digenea]. Monogr. Parazytol., 15, 169 pp. (In Polish)

NiEWIADOMSKA, K. (2010): [Trematoda, The general part; systematic part - Aspidogastrea, Digenea: Strigeida], Fauna Słodkowodna Polski, 34 A, Polish Hydrobiological Society, University of Łódź, Łódź, 388 pp. (In Polish)

NiEWIAdOMSKA, K., LASKOWSKI, Z. (2002): Systematic relationships among six species of Diplostomum Nordmann, 1832 (Digenea) based on morphological and molecular data. Acta Parasitol., 47(1): 20 - 28. ICID: 7017 Odening, K. (1978): Trematodenliste der DDR, Angew. Parasitol., 19: 168 - 186

PojmańsKa, T., Niewiadomska, K., OKulewicz, A. (2007): [Parasitic helminths in Poland. Species, hosts, blank spots]. Polish Parasitological Society, Warsaw, 360 pp. (In Polish)

RUszKowsKi, J. (1925): [Materials for Helminthological Fauna of Poland] Part 1. Sprawozdania Komisyi Fizyograficznej Akademyi Umiejętności 60: 173 - 185 (In Polish) RzĄD, I., SitKo, J., KAVETSKA, K., KANAREK, G. (2007): Preliminary research of Digenea of the Western Pomeranian wild ducks, Wiad. Parazytol., 53 Supl., 32 (In Polish) RZĄD, I., SitKO, J., KAVETSKA, K., KALISIŃSKA, E., PANICZ, R. (2013): Digenean communities in the tufted duck [Aythya fuligula (L., 1758)] and greater scaup [A. marila (L., 1761)] wintering in the north-west of Poland. J. Helminthol., 87(02): 230 - 239. DOI: 10.1017/S0022149X12000284

SCHIGIN, A. A. (1993): [Trematodes from the Russian Fauna and Adjacent Regions: the Genus Diplostomum: Maritae] Nauka, Moskva, 208 pp. (In Russian)

SERGEEVA, T. P. (1973): [Some rare species of trematodes in Lariform birds] Trudy Gel'mintologicheskoi Laboratorii 23, 140 - 144. (In Russian)
SitKo, J., FALtÝNKOVÁ, A., SchOlZ T. (2006): Checklist of the Trematodes (Digenea) of Birds of the Czech and Slovak Republics. Academia, Praha. 111 pp.

SMOGORZEVSKAYA, L. A. (1976): [Helminths Infecting Waterfowl and Wading Birds in Ukraine]. Naukova Dumka, Kiev, 416 pp. (In Russian)

Sudarikov, V., KurochKIN, Y. V. (1968): [Systematic position and development of the metacercaria „Neodiplostomum scardinii” Schulman, 1952 parasitic in the brain of fish] Sbornik Gelmintologicheskikh Rabot. Trudy Astrakchanskogo Zapovednika, 11, 255 - 273 (In Russian)

SulgostowskA, T. (1958): Flukes of birds of Drużno Lake. Acta Parasitol., 6(3): 111 - 142

SulgostowsKA, T. (2007): Intestinal digeneas of birds (superfamily Diplostomoidea) of the Masurian lakes. Wiad. Parazytol., 53(2): $117-128$

SulgostowskA, T., CZAPlińsKA, D. (1987): [The Catalogue of Polish Parasitological Fauna. Parasites of Birds, The Protozoa and the Trematoda]. Part IV, Vol 1. PWN, Warszawa-Wrocław, 210 pp. (In Polish)

Sulgostowska, T., Vojtkova, L. (2005): Parasites of sticklebacks (Actinopterygii: Gasterosteidae) from southeastern Baltic Sea (Poland). Wiad. Parazytol., 51(2): 151 155

Tokobaev, M. M., Tschibichenko, N. T. (1978): [Trematodes of Fauna in Kyrgyzstan], 233 pp. (In Russian) VAIDOVA, S. M. (1978): [Helminths in birds from Azerbaidain]. Baku, Izdat. Elm, 328 pp. (In Russian).

Yamaguti, S. (1971): Synopsis of Digenetic Trematodes of Vertebrates. Vol I., II. Keigaku Publishing, Tokyo, 1074 pp., 349 plates.

YAMAGUTI, S. (1975): A synoptical review of the life history of digenetic trematodes of vertebrates, with a special reference to the morphology of their larval forms. Keigaku Publishing, Tokyo, Japan, 590 pp. 